\title{
The effect of Yeast Strain, Grape Solids, Nitrogen and Temperature on Fermentation Rate and Wine Quality"
}

\section{A TROMP}

Viticultural and Oenological Research Institute (VORI), Private Bag X5026,

7600, Stellenbosch, Republic of South Africa.

The technical assistance of Miss E E J Simpson is gratefully acknowledged.

Submitted for publication: August 1983

Accepted for publication: March 1984

\begin{abstract}
The effect of four yeast strains, two levels of grape solids, two nitrogen levels and three fermentation temperatures viz. $10^{\circ}$, $13^{\circ}$ and $15^{\circ} \mathrm{C}$ on total fermentation time (TFT) and wine quality was studied in a factorial experiment by employing a nitrogen deficient Chenin blanc must. It was found that the presence of solids, addition of nitrogen and fermenting at $15^{\circ} \mathrm{C}$ decreased TFT dramatically. Nitrogen was the only factor which also increased wine quality, the other two having a detrimental effect. At optimum levels of nitrogen, yeast strains WE 452 and WE 500 (VORI collection) reduced TFT without detrimentally affecting wine quality. In the case of WE 452, no solids should be present and fermentation conducted at $10^{\circ} \mathrm{C}-13^{\circ} \mathrm{C}$, and in the case of WE 500, traces of solids should be present and a fermentation temperature of between $13^{\circ} \mathrm{C}-15^{\circ} \mathrm{C}$ should be utilized. Under these conditions WE 452 and WE 500 reduce TFT from $\mathrm{C} .76$ days to as few as C.30 and C.15 days respectively.
\end{abstract}

It has been established that several factors contribute to the occurrence of stuck or lagging fermentations. Low levels of nitrogen (Agenbach, 1977; Vos, Zeeman \& Heymann, 1978; Van Rooyen \& Tromp, 1982) and absence or low levels of grape solids (Groat \& Ough, 1978; Houtman \& Du Plessis, 1981; Van Rooyen \& Tromp, 1982) seem to be the two main factors in this respect. Although oxygen is required for sterol synthesis (Aries \& Kirsop, 1978) which is necessary to complete fermentation (Larue, Lafon-Lafourcade \& RibéreauGayon, 1979; Strydom, Kirschbaum \& Tromp, 1982), its addition to must is detrimental to wine quality (Tromp, 1980; Houtman \& Du Plessis, 1981). The latter authors also pointed out that the oxygen concentration of musts is sufficiently high (C.8 mg. $\left.l^{-1}\right)$ under practical conditions for fermentations to proceed to dryness. Low temperatures also retards fermentation. Ough (1966) reported a $50 \%$ reduction in fermentation time when fermentation temperature was increased from $10^{\circ} \mathrm{C}$ to $21^{\circ} \mathrm{C}$. Van Rooyen \& Tromp (1982) similarly found that fermentation took 14,6 days on average at $20^{\circ} \mathrm{C}$ as against 20,6 days at $13^{\circ} \mathrm{C}$.

It was found by Groat \& Ough (1978) that bentonite or talc addition to clear must stimulated fermentation but Van Rooyen \& Tromp (1982) could not confirm these results. This was probably due to the yeast strain which was employed in the latter study. The strain was WE 14 from the VORI collection and, being a bottom fermentor, was probably flocculated from suspension by the added bentonite.

The purpose of this study was to investigate the effect of grape solids, nitrogen addition and temperature of fermentation on the performance of different yeast strains, primarily with regard to TFT and the quality of the resultant wines.

\section{MATERIALS AND METHODS}

Must Treatments: Must from a Chenin blanc vineyard, known to be prone to stuck or lagging fermentation, mainly because of a nitrogen deficiency (Agenbach, 1977; Van Rooyen \& Tromp, 1982), was used in this study. The analysis of the must was as follows:

$$
\begin{array}{ll}
\text { Reducing sugar } & =225 \mathrm{~g} \cdot \ell^{-1} \text { (as invert sugar) } \\
\text { Fixed acidity } & =9,8 \mathrm{~g} \cdot \ell^{-1} \text { (as tartaric acid) } \\
\text { pH } & =3,08 \\
\text { Amino nitrogen } & =98 \mathrm{mg} \cdot l^{-1} \text { (as lysine) } \\
& \quad \text { (Anon., 1973) } \\
\text { Total nitrogen } & =270 \mathrm{mg} \cdot l^{-1} \text { (as N). }
\end{array}
$$

The must was subdivided into 48 duplicate fermentations in $20 \ell$ stainless steel containers and sulphur dioxide added to $50 \mathrm{mg} . \mathrm{l}^{-1}$. Using a factorial design the following treatments were applied:

- Two levels of grape solids viz:

no solids $\left(\mathrm{S}_{1}\right)$ - obtained by filtration of settled juice; traces of solids $\left(\mathrm{S}_{2}\right)$ - obtained by clear settling of the juice (although slightly turbid, no grape solids could be determined by centrifugation).

- Two levels of nitrogen viz:

270 and 520 mgN. $\ell^{-1}$ must $\left(\mathrm{N}_{1}\right.$ and $\mathrm{N}_{2}$ respectively. Adjusted by the addition of $\left.\left(\mathrm{NH}_{4}\right)_{2} \mathrm{HPO}_{4}\right)$.

- Four yeast strains viz: WE 452, WE 500, WE 14 and WE 432 of the VORI collection.

- Three fermentation temperatures viz: $10^{\circ} \mathrm{C}, 13^{\circ} \mathrm{C}$ and $15^{\circ} \mathrm{C}$.

Inoculations of $5 \times 10^{6}$ yeast cells $/ \mathrm{ml}$ must were made by adding the rehydrated dried yeast directly to each stainless steel container. Fermentation rates were recorded by daily mass determinations and periodic sugar analyses towards the end of fermentation. At dryness TFT was noted and the wines filtered and cold stabilized $\left(0^{\circ} \mathrm{C}\right)$. Those wines which were still fermenting 76 days

1) Paper presented at the 18th Congress of the Office International de la Vigne et du Vin (OIV), Cape Town, 1983. 
after inoculation were also filtered and cold stabilized. After a second filtration and bottling all the wines were stored at $0^{\circ} \mathrm{C}$ to prevent any changes in the quality and/or composition of the wines. The wines were subsequently analysed for: Density $\left(20^{\circ} \mathrm{C}\right)$, alcohol (vol. \%), extract $\left(\mathrm{g} . \ell^{-1}\right)$, total reducing sugars $\left(\mathrm{g} . \ell^{-1}\right)$, volatile acidity $\left(\mathrm{g} . \ell^{-1}\right)$ and free and total sulphur dioxide by employing methods of Anon. (1975).

Wine quality (overall impression as well as aroma) was determined by employing the 9-point scorecard as discussed by Tromp \& Conradie (1979) utilizing a panel of 12 expert judges. The scores were expressed as a percentage.

Data Processing: An analysis of variance was performed on the data and use was also made of the Scott-Knott method of grouping means in a cluster analysis (Scott \& Knott, 1974).

\section{RESULTS AND DISCUSSION}

Raw data: To give an idea of the magnitudes and variation within the data set a summary of analytical results and quality ratings is given in Table 1.

As can be seen in Table 1 TFT varied from 76 to 12 days, and the overall quality of the resultant wines from $31,4 \%$ to $63,0 \%$ in response to the treatments mentioned before.

In Table 2 the composite means of the different parameters measured are shown. Data of density, alcohol and extract was omitted as some wines did not ferment to dryness. Percentage free sulphur dioxide (of total sulphur dioxide) was calculated from and given in place of free and total sulphur dioxide.

Main effects: The main effects of the different treatments on TFT can be seen in Table 2. It is evident that all the treatments had a significant effect on TFT. The presence of grape solids, even in such small quantities that it could not be determined by centrifugation, shortened TFT from 62,4 to 40,3 days. This is in accordance with the
TABLE 1

Magnitude and variation of analytical and sensory data obtained in this study.

\begin{tabular}{|c|c|c|c|c|}
\hline Variable & Mean & Minimum & Maximum & $\begin{array}{l}\text { Standard } \\
\text { deviation }\end{array}$ \\
\hline $\begin{array}{l}\text { Total ferm. time } \\
\text { (days) }\end{array}$ & 51 & 12 & 76 & 5,8 \\
\hline Density $\left(20^{\circ} \mathrm{C}\right)$ & 0,99205 & 0,99059 & 0,99770 & 0,00047 \\
\hline Alcohol (vol. \%) & 13,25 & 12,51 & 13,57 & 0,14 \\
\hline Extract $\left(\mathrm{g} \cdot \ell^{-1}\right)$ & 24 & 21 & 38 & 1 \\
\hline Sugar $\left(\mathrm{g} \cdot \mathrm{l}^{-1}\right)$ & 3,5 & 1,1 & 15,4 & 1,3 \\
\hline $\begin{array}{l}\text { Total acidity } \\
\left(\mathrm{g} \cdot \ell^{-1}\right)\end{array}$ & 7,55 & 7,10 & 7,95 & 0,14 \\
\hline $\begin{array}{l}\text { Volatile acidity } \\
\left(\mathrm{g} \cdot \ell^{-1}\right)\end{array}$ & 0,43 & 0,18 & 0,59 & 0,04 \\
\hline $\mathrm{pH}$ & 3,07 & 2,86 & 3,29 & 0,05 \\
\hline $\begin{array}{l}\mathrm{SO}_{2} \\
\left(\text { free, mg. } \ell^{-1}\right)\end{array}$ & 40 & 24 & 50 & 6 \\
\hline $\begin{array}{l}\mathrm{SO}_{2} \\
\text { (total, mg. } \ell^{-1} \text { ) }\end{array}$ & 90 & 55 & 116 & 10 \\
\hline$\%$ Free $\mathrm{SO}_{2}$ & 45 & 17 & 63 & 9 \\
\hline $\begin{array}{l}\text { Overall } \\
\text { quality }(\%)\end{array}$ & 51,4 & 31,4 & 63,0 & 3,8 \\
\hline $\begin{array}{l}\text { Aroma } \\
\text { quality }(\%)\end{array}$ & 51,3 & 32,4 & 63,0 & 3,2 \\
\hline
\end{tabular}

studies of Groat \& Ough (1978) and Van Rooyen \& Tromp (1982). The addition of nitrogen also decreased TFT from 56,3 to 46,4 days on average as was expected and previously pointed out by Agenbach (1977) on must from the same vineyard in that year.

The yeast strain employed had a marked effect on TFT, WE 452 completing fermentations at 33,6 days on average, while WE 500, WE 432 and WE 14 respectively took $47,1,59,3$ and 65,5 days to do the same.

In the case of fermentation temperature the wellknown fact that fermentation is slower at lower temperatures was established once more; under the same set of conditions fermentation at $15^{\circ} \mathrm{C}, 13^{\circ} \mathrm{C}$ and $10^{\circ} \mathrm{C}$ caused TFT's of respectively $38,0,54,4$ and 61,6 days on average.

From the above it should follow that to obtain the shortest TFT in terms of the treatments applied, traces of

TABLE 2

Wine parameter data as affected

by several treatments of a Chenin blanc must

\begin{tabular}{|c|c|c|c|c|c|c|c|c|}
\hline \multirow[b]{2}{*}{ Treatments } & \multicolumn{8}{|c|}{ Wine parameters } \\
\hline & $\begin{array}{l}\text { TFT } \\
\text { (days) }\end{array}$ & $\begin{array}{l}\text { Sugar } \\
\left(\mathrm{g} \cdot \ell^{-1}\right)\end{array}$ & $\begin{array}{l}\text { Total } \\
\text { acidity } \\
\left(\text { g. } \ell^{-1}\right)\end{array}$ & $\begin{array}{l}\text { Volatile } \\
\text { acidity } \\
\left(\text { g. } \ell^{-1}\right)\end{array}$ & $\mathrm{pH}$ & $\begin{array}{l}\text { Overall } \\
\text { quality } \\
(\%)\end{array}$ & $\begin{array}{l}\text { Aroma } \\
\text { quality } \\
(\%)\end{array}$ & $\begin{array}{l}\text { Percentage } \\
\text { Free } \\
\mathrm{SO}_{2}\end{array}$ \\
\hline No grape solids & $\stackrel{*}{62,4 \text { A }}$ & $\begin{array}{ll}* \\
5,0 & A\end{array}$ & 7,53 & 0,48 & 3,09 & $\stackrel{*}{54,3 \text { A }}$ & ${ }_{55,0}^{*} \mathrm{~A}$ & 46 \\
\hline Traces of grape solids & $40,3 \mathrm{~B}$ & $2,1 \mathrm{~B}$ & 7,56 & 0,38 & 3,05 & $47,6 \mathrm{~B}$ & $47,7 \mathrm{~B}$ & 45 \\
\hline No nitrogen & $\stackrel{* *}{56,3 \text { A }}$ & $\stackrel{* *}{4,1 \quad \mathrm{~A}}$ & $\stackrel{* *}{7,39} \mathrm{~B}$ & $\stackrel{* *}{0,46 \quad \mathrm{~A}}$ & ${ }_{3,11}^{*} \mathrm{~A}$ & $\stackrel{* *}{48,4} \mathrm{~B}$ & $\stackrel{*}{48,3}$ B & 45 \\
\hline Addition of nitrogen & $46,4 \mathrm{~B}$ & 2,9 B & $7,70 \mathrm{~A}$ & $0,40 \mathrm{~B}$ & $3,03 \mathrm{~B}$ & $54,5 \mathrm{~A}$ & $54,3 \mathrm{~A}$ & 47 \\
\hline Yeast strain WE 452 & $\stackrel{* *}{33,6 \mathrm{D}}$ & $\stackrel{* *}{1,5} \mathrm{D}$ & $\begin{array}{l}* * \\
7,45\end{array}$ & $\stackrel{* *}{0,50 \quad \mathrm{~A}}$ & $\begin{array}{l}* * \\
3,01 \quad \mathrm{C}\end{array}$ & $\begin{array}{l}* * \\
48,7\end{array}$ & $\begin{array}{l}* * \\
49,6 \mathrm{C}\end{array}$ & $\begin{array}{ll}* * \\
37 & \mathrm{D}\end{array}$ \\
\hline Yeast strain WE 500 & $47,1 \mathrm{C}$ & $4,7 \mathrm{~B}$ & $7,55 \mathrm{~B}$ & $0,43 \mathrm{C}$ & $3,07 \mathrm{~B}$ & $53,4 \mathrm{~A}$ & $53,9 \mathrm{~A}$ & $48 \mathrm{~B}$ \\
\hline Yeast strain WE 14 & $65,5 \mathrm{~A}$ & $5,0 \mathrm{~A}$ & $7,50 \mathrm{C}$ & $0,46 \mathrm{~B}$ & $3,13 \mathrm{~A}$ & $54,2 \mathrm{~A}$ & $52,6 \mathrm{~B}$ & $44 \mathrm{C}$ \\
\hline Yeast strain WE 432 & $59,3, \mathrm{~B}$ & $2,9 \mathrm{C}$ & $7,69 \mathrm{~A}$ & $0,33 \mathrm{D}$ & $3,06 \mathrm{~B}$ & 49,4 B & $49,3 \mathrm{C}$ & $54 \mathrm{~A}$ \\
\hline $15^{\circ} \mathrm{C}$ & $\stackrel{* *}{38,0 \mathrm{C}}$ & $\stackrel{* *}{2,1} \mathrm{C}$ & 7,53 & $\stackrel{* *}{0,40 \quad \mathrm{C}}$ & $\stackrel{* *}{3,04 \mathrm{C}}$ & $\stackrel{* *}{49,5 \mathrm{C}}$ & $\stackrel{* *}{47,9 \text { B }}$ & 44 \\
\hline $13^{\circ} \mathrm{C}$ & $54,4 \mathrm{~B}$ & $3,4 \mathrm{~B}$ & 7,56 & 0,42 B & $3,07 \mathrm{~B}$ & $51,9 \mathrm{~B}$ & $52,9 \mathrm{~A}$ & 45 \\
\hline $10^{\circ} \mathrm{C}$ & $61,6 \mathrm{~A}$ & $5,1 \mathrm{~A}$ & 7,56 & $0,46 \mathrm{~A}$ & $3,09 \mathrm{~A}$ & 52,9 A & $53,2 \mathrm{~A}$ & 48 \\
\hline Average & 51,34 & 3,52 & 7,55 & 0,43 & 3,07 & 51,1 & 51,3 & 45,8 \\
\hline
\end{tabular}

(1) *and** denotes significance at levels $\mathrm{P} \leqslant 0,05$ and $\mathrm{P} \leqslant 0,01$ respectively

(2) The letters A-C designates groups which are significantly different according to Scott \& Knott (1974) 
grape solids should be present in the must, nitrogen should be added, WE 452 should be employed as yeast strain and fermentation should proceed at a temperature of $15^{\circ} \mathrm{C}$. It was in fact found in this experiment that application of these conditions yielded the shortest TFT, namely 12 days. The longest TFT should (Table 2) be encountered when using filtered must to which no nitrogen is added while fermentation is conducted with yeast strain WE 14 at $10^{\circ} \mathrm{C}$. This was found to be the case - these conditions caused a TFT of 76 days - at which time all those fermentations which had not proceeded to dryness were stopped. The fermentation curves for the two above-mentioned fermentations are given in Fig. 1. measured. Although differences occurred between yeast strains as far as TA and $\mathrm{pH}$ were concerned these were of no practicalsignificance. WE 452 formed more VA than did any of the other strains $\left(0,5 \mathrm{~g} \cdot \ell^{-1}\right)$ while WE 500 formed less $\left(0,43 \mathrm{~g} \cdot \mathrm{l}^{-1}\right)$ than either WE 452 or WE $14(0,5$ and $\left.0,46 \mathrm{~g} \cdot \mathrm{\ell}^{-1}\right)$. It is also apparent that WE 452 forms more $\mathrm{SO}_{2}$-binding substances such as aldehydes than the other yeast strains - the $\%$ free $\mathrm{SO}_{2}$ being markedly less than in the case of WE $500(48 \%)$ and WE $432(54 \%)$. This would mean that wines fermented with WE 452 will require a higher concentration of total sulphur dioxide than the other yeast strains to retain the same amount of free $\mathrm{SO}_{2}$ in the wine.

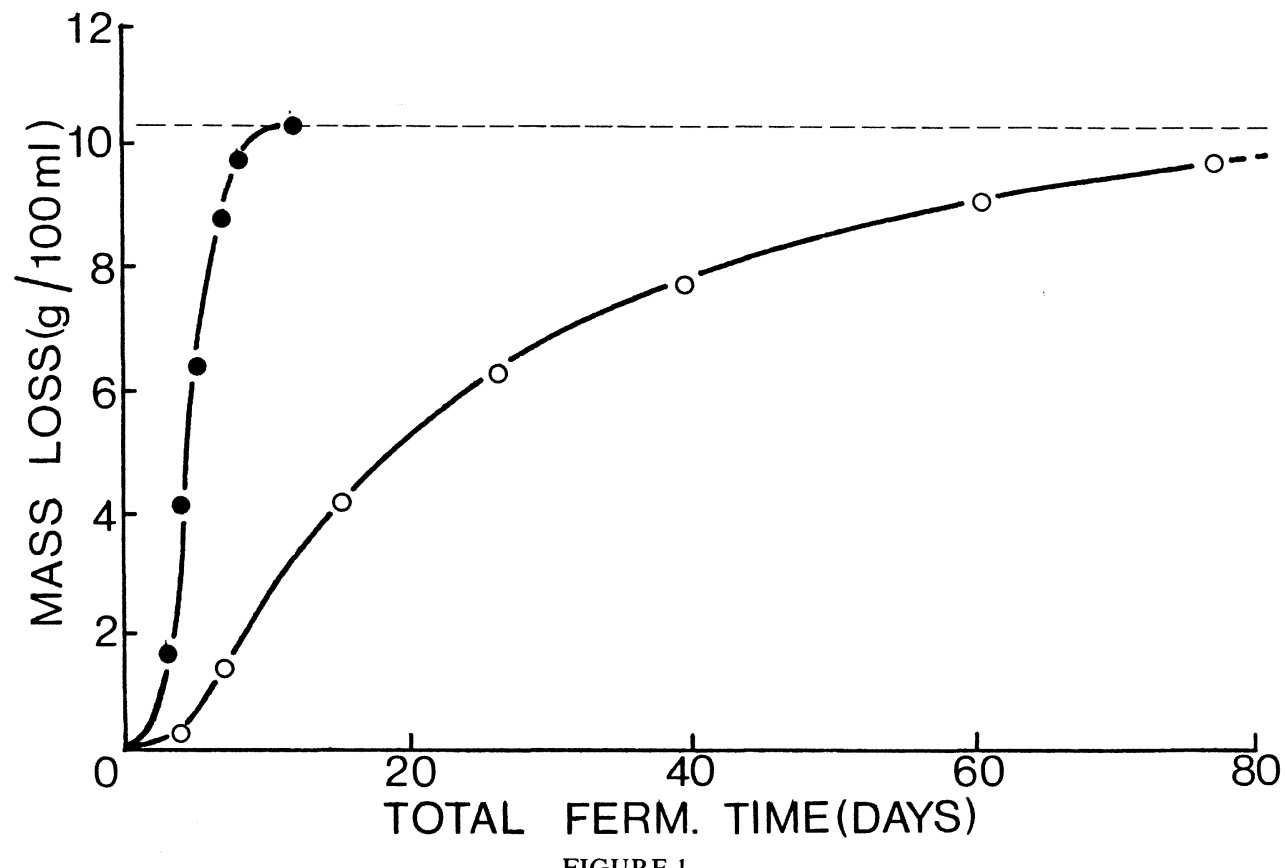

FIGURE 1

Fermentation curves in a Chenin blanc must of yeast strains WE 452 (in the presence of solids, with addition of nitrogen at $15^{\circ} \mathrm{C} \bullet$ ) and WE 14 (in filtered must with no nitrogen added at $10^{\circ} \mathrm{C}-\mathrm{O}$ ).

All the treatments had a significant effect on quality (Table 2). As in previous research (Houtman \& Du Plessis, 1981; Van Rooyen \& Tromp, 1982) the presence of grape solids had a negative effect on wine quality $(47,6 \%$ as against $54,3 \%$ where solids were absent). The addition of nitrogen increased wine quality from $48,4 \%$ to $54,5 \%$ on average. Note that the addition of nitrogen increased both fermentation rate and wine quality. This was also found by Vos, Zeeman \& Heymann (1978) and Van Rooyen \& Tromp (1982).

The yeast strain employed also had a marked effect on wine quality, WE 500 and WE 14 yielding wines of higher quality than those fermented with WE 452 and WE 432 $(53,4 \%$ and $54,2 \%$ as against $48,7 \%$ and $49,4 \%$ respectively). Lower temperatures increased wine quality $(52,9 \%$, $51,9 \%$ and $49,5 \%$ for $10^{\circ} \mathrm{C}, 13^{\circ} \mathrm{C}$ and $15^{\circ} \mathrm{C}$ respectively).

The effect of the different treatments on the total - and volatile acidity concentrations (TA \& VA) as well as on $\mathrm{pH}$ and $\%$ free sulphur dioxide will now be discussed in brief (Table 2).

The presence or absence of grape solids had no significant effect on these measurements. The addition of nitrogen, however, caused a higher TA in the resultant wines with $\mathrm{pH}$ and $\mathrm{VA}$ being lower. While lower fermentation temperature only caused higher $\mathrm{VA}$ and $\mathrm{pH}$, the yeast strain employed had an effect on all four parameters
Interactions affecting TFT and wine quality: The main interaction which occurred affecting both TFT and quality was between the presence of solids and addition of nitrogen (Table 3).

TABLE 3

Composite means for total fermentation time (TFT) and wine quality as affected by grape solids and nitrogen.

\begin{tabular}{lllll}
\hline \multirow{2}{*}{$\begin{array}{l}\text { Grape } \\
\text { Solids }\end{array}$} & \multicolumn{2}{c}{ No nitrogen added } & \multicolumn{2}{c}{ Nitrogen added } \\
\cline { 2 - 5 } & TFT (days) & Qual. (\%) & TFT (days) & Qual. (\%) \\
\hline None & 65,5 & 54,3 & 59,3 & 56,2 \\
Traces & 47,1 & 42,6 & 33,6 & 52,9 \\
\hline
\end{tabular}

LSD (TFT) $P \leqslant 0,01=2$ days

LSD (Quality) $P \leqslant 0,01=3,6 \%$

$$
P \leqslant 0,05=2,8 \%
$$

Calculated for the solids $\mathrm{x}$ nitrogen interaction.

In the absence of solids TFT was marginally decreased from 65,5 to 59,3 days by the addition of nitrogen, while wine quality was virtually unaffected. The presence of solids reduced TFT whether nitrogen was added or not. At the lower nitrogen level wine quality, however, was severely impaired by the presence of solids $(42,6 \%$ as against $54,3 \%$ ), while only a slight, but significant loss in 
quality was encountered when solids were present at the higher level of nitrogen $(52,9 \%$ as against $56,2 \%)$. What is however of greater importance is that the presence of only traces of grape solids decreased TFT from 65,5 to 33,6 days on average when also increasing the nitrogen level, while wine quality was not at all affected $(54,3 \%$ as against $52,9 \%$ ). These results are the average for four yeast strains and are in accordance with the results obtained by Tromp (1980) where the same relationship between presence of solids and nitrogen addition was shown for only one yeast strain (WE 14). This interaction cannot be explained at present.

This relationship $(\mathrm{S} \times \mathrm{N})$ was somewhat different for the different yeast stains. In Fig. 2 the effect of grape solids and nitrogen addition on TFT (Fig. 2A) and wine quality (Fig. 2B) is given for the different yeast strains in a three-dimensional outlay. When no solids were present or no nitrogen was added $\left(\mathrm{S}_{1} \mathrm{~N}_{1}\right.$, Fig. $\left.2 \mathrm{~A}\right)$, WE 452 had a TFT of 50,5 days which was significantly shorter than the $73,7,70,7$ and 67,0 days for WE 500, WE 14 and WE 432 respectively. When no solids were present but nitrogen was added $\left(\mathrm{S}_{1} \mathrm{~N}_{2}\right)$, TFT was drastically reduced for WE 452 (to 27,5 days), somewhat reduced for WE 500 (to 68,7 days) but stayed the same for WE 14 and WE 432 , although the residual reducing sugars were slightly less where nitrogen was added (see numbers in brackets, Fig. 2A).

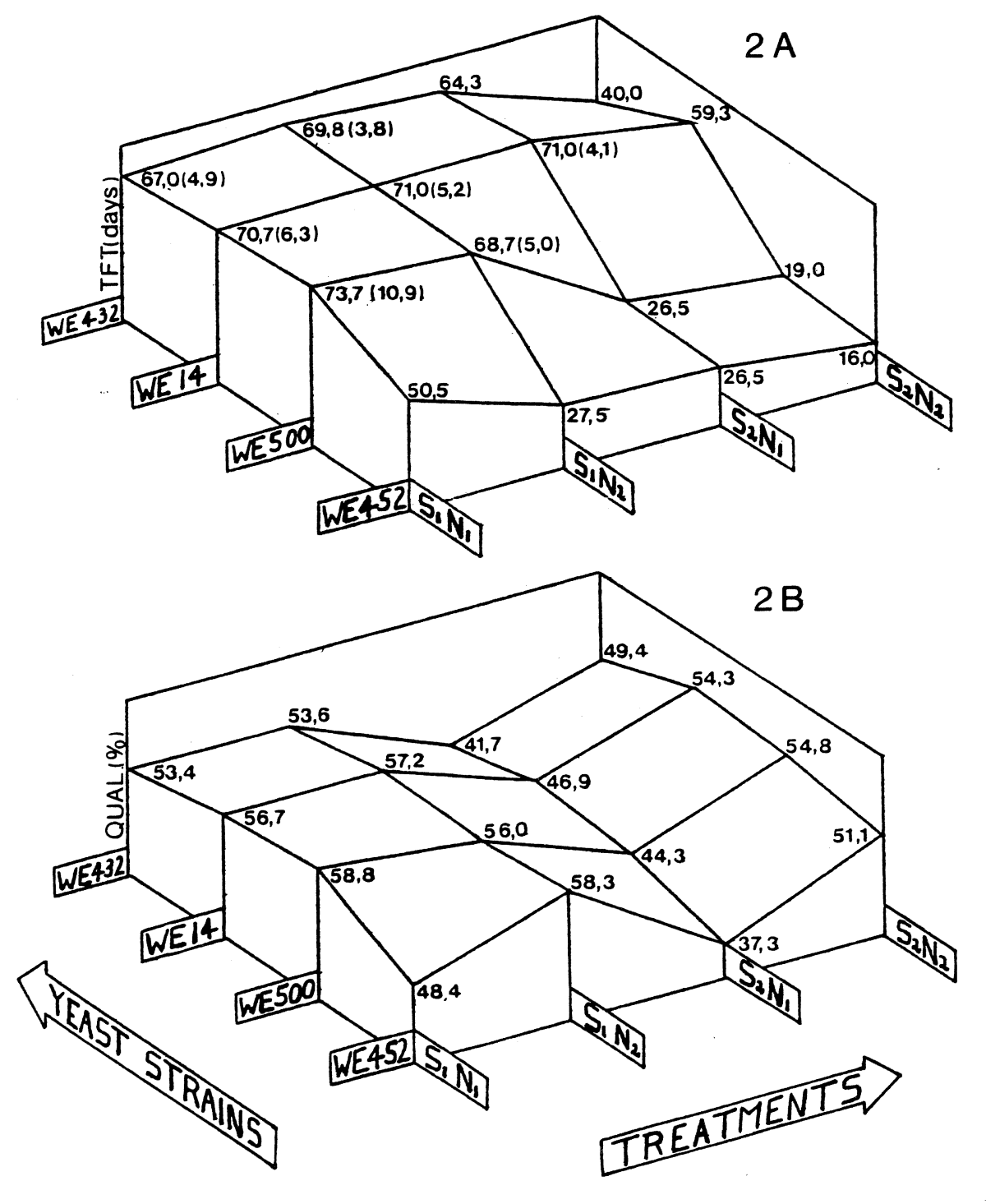

FIGURE 2

Effect of yeast strain, presence of solids and addition of nitrogen on total fermentation time (TFT, Fig. 2A) and wine quality (Fig. 2B).

$\mathrm{S}_{1}=$ no solids

$\mathrm{S}_{2}=$ traces of solids

$\mathrm{N}_{1}=$ no nitrogen

$\mathrm{N}_{2}=$ addition of nitrogen

$$
\begin{aligned}
& \text { LSD (TFT) } P \leqslant 0,05=4,4 \text { days } \\
& P \leqslant 0,01=5,2 \text { days } \\
& \text { LSD (Qual). } P \leqslant 0,05=7,7 \% \text {, } \\
& P \leqslant 0,01=8,8 \%
\end{aligned}
$$

Calculated for the

yeast strain $\mathrm{x}$ solids $\mathrm{x}$ nitrogen interaction

Numbers in brackets in Fig. 2A denotes $g$ residual reducing sugar. $\ell^{-1}$ after 76 days of fermentation. 
In the presence of solids but without nitrogen addition $\left(\mathrm{S}_{2} \mathrm{~N}_{1}\right)$ TFT was drastically reduced to the same level (viz. 26,5 days) for both WE 452 and WE 500, while for WE 14 and WE 432 TFT was virtually unaffected (residual reducing sugar concentration being, however, once again lower). In the case of nitrogen addition in the presence of solids $\left(\mathrm{S}_{2} \mathrm{~N}_{2}\right)$ TFT was reduced for all four strains to 16,0 , $19,0,59,3$ and 40,0 days for WE 452, WE 500, WE 14 and WE 432 respectively.

From the above it is evident that the relationship between the presence of solids and the addition of nitrogen and its effect on TFT holds true in general. When, however, yeast strains WE 432 and WE 14, were used, the addition of nitrogen in the absence of solids did not decrease TFT. Similarly the presence of solids at too low a level of nitrogen did not decrease TFT for these two yeast strains (Fig. 2A). The yeast strain WE 500 reacted somewhat differently and seemed to be much more sensitive to solids than to the addition of nitrogen. WE 452, on the other hand, completed fermentation in the absence of both solids and additional nitrogen, while these two factors individually and jointly decreased TFT.

As far as quality is concerned, it was previously established in this paper that the addition of nitrogen increased, while the presence of solids decreased wine quality unless, in the latter instance, nitrogen was added (Table 3). This seems to be true when evaluating the effects of these treatments on the yeast strains individually (Fig. 2B). WE 452, however, seems to be more sensitive to the lower nitrogen level at which poorer wines were yielded.

It is evident from Fig. 2 that to shorten TFT without loss of quality the $\mathrm{S}_{2} \mathrm{~N}_{2}$ treatment for all yeast strains as well as the $S_{1} N_{2}$ treatment for WE 452 merits further study. The effect of these treatments on TFT and wine quality is given for the different fermentation temperatures in Table 4.

Although the data in Table 4 do not always differ significantly from column to column it is evident that there is a tendency for quality to be higher in the case of WE 452 when lower fermentation temperatures are applied. For WE 14 and WE 500 it is just the opposite, $15^{\circ} \mathrm{C}$ favouring the better quality wines. When WE 452 is used as yeast strain it is clear that must should be as clear from solids as possible, while fermentation should proceed at $10^{\circ}-13^{\circ} \mathrm{C}$. Under these conditions TFT's of 25-39 days will be encountered without quality being adversely affected. However when WE 500 is used, traces of solids must be present and fermentation conducted at $13^{\circ} \mathrm{C}$ $-15^{\circ} \mathrm{C}$ causing TFT's of 12-18 days, once again without effect on wine quality. Yeast strains WE 14 and WE 432 should not be used when problems with stuck or lagging fermentations can be expected.

\section{CONCLUSIONS}

To regulate fermentation speed and subsequent wine quality the importance of the interaction between the presence of solids, nitrogen level of the must, fermentation temperature and yeast strain employed is evident. In all instances it was found that the nitrogen level of musts should be adjusted (Vos, Crous \& Swart, 1980), which has the additional advantage of curbing $\mathrm{H}_{2} \mathrm{~S}$ production (Vos \& Gray, 1979).

Of the four yeast strains employed WE 452 and WE 500 were the only two by which fast fermentation could be obtained while retaining wine quality. In the case of WE 452 no grape solids should be present, while fermentation temperature should be between $10-13^{\circ} \mathrm{C}$. At these conditions fermentation will take about 30 days. When WE 500 is used traces of solids must be present to increase fermentation speed, while fermentation temperatures of $13^{\circ} \mathrm{C}-15^{\circ} \mathrm{C}$ favour higher wine quality. Such fermentations will proceed for, on average, 12-18 days.

Strain WE 500 formed less volatile acidity and produced wine requiring less $\mathrm{SO}_{2}$ than WE 452. Under practical conditions, where some solids are usually present, strain WE 500 causes fermentation times as short as does WE 452 but with the retention of wine quality. To curb the occurrence of stuck fermentations the yeast strain WE 500 should therefore be used, traces of solids should be present in must, while the level of nitrogen should be adjusted and fermentation, should proceed at $13^{\circ} \mathrm{C}$ $15^{\circ} \mathrm{C}$. At the same time wine quality will not be adversely affected.

It is evident that future research should be aimed at the selection of new yeast strains as well as at the determination of those components of grape solids which so drastically influence both fermentation speed and wine quality.

TABLE 4

The effect of yeast strain, grape solids and

fermentation temperature on total fermentation time (TFT)

and wine quality (nitrogen was added to a level of $520 \mathrm{mg} \cdot \ell^{-1}$ )

\begin{tabular}{|c|c|c|c|c|c|c|c|}
\hline \multirow{3}{*}{$\begin{array}{l}\text { Yeast } \\
\text { strain }\end{array}$} & \multirow{3}{*}{$\begin{array}{l}\text { Grape } \\
\text { solids }\end{array}$} & \multicolumn{6}{|c|}{ Temperature } \\
\hline & & \multicolumn{2}{|c|}{$10^{\circ} \mathrm{C}$} & \multicolumn{2}{|c|}{$13^{\circ} \mathrm{C}$} & \multicolumn{2}{|c|}{$15^{\circ} \mathrm{C}$} \\
\hline & & TFT (days) & Qual. (\%) & TFT (days) & Qual. (\%) & TFT (days) & Qual. (\%) \\
\hline WE 452 & None & 39 & 62,1 & 25 & 59,3 & 18 & 53,7 \\
\hline WE 452 & Traces & 21 & 54,2 & 15 & 50,8 & 12 & 48,2 \\
\hline WE 500 & Traces & 27 & 51,4 & 18 & 55,1 & 12 & 57,9 \\
\hline WE 14 & Traces & 76 & 51,4 & 61 & 53,7 & 41 & 63,0 \\
\hline WE 432 & Traces & 61 & 49,1 & 41 & 47,0 & 18 & 50,9 \\
\hline
\end{tabular}

$$
\begin{array}{r}
\text { LSD (TFT) } P \leqslant 0,05=5,9 \text { days } \\
P \leqslant 0,01=6,8 \text { days } \\
\text { LSD (Quality) } P \leqslant 0,05=10,0 \% \\
P \leqslant 0,01=11,9 \%
\end{array}
$$

Calculated for the yeast strain $\mathrm{x}$ nitrogen $\mathrm{x}$ solids $\mathrm{x}$ temperature interaction. 


\section{LITERATURE CITED}

AGENBACH, W.A., 1977. A study of must nitrogen content in relation to incomplete fermentations, yeast production and fermentation activity. Proc. S. Afr. Soc. Enol. Vitic., 66-68.

ANONYMOUS, 1973. E.B.C. Analysis Committee. The EBC-ninhydrin method for the determination of free Alpha-amino nitrogen. J. Inst. Brew. 79, 37-41.

ANONYMOUS, 1975. "Official Methods of Analysis." A.O.A.C. 11 th ed. Association of Official Analytical Chemists, Washington, D.C.

ARIES, V. \& KIRSOP, B.H., 1978. Sterol biosynthesis by strains of Saccharomyces cerevisiae in the presence and absence of dissolved oxygen. J. Inst. Brew. 84, 118-122.

GROAT, M. \& OUGH, C.S., 1978. Effects of insoluble solids added to clarified musts on fermentation rate, wine composition and wine quality. Am. J. Enol. Vitic. 29, 112-119.

HOUTMAN, A.C. \& DU PLESSIS, C.S., 1981. The effect of juice clarity and several conditions promoting yeast growth on fermentation rate, the production of aroma components and wine quality. S. Afr. J. Enol. Vitic. 2, 71-81.

LARUE, F., LAFON-LAFOURCADE, S. \& RIBEREAU-GAYON, P., 1979. Les différents rôles fonctionnels des stéroïdes sur les levures dans le moût de raisin en fermentation: notion de facteur de survie. Ann. Microbiol. (Inst. Pasteur) 130A, 231-243.
OUGH, C.S., 1966. Fermentation rates of grape juice II. Effects of initial ${ }^{\circ}$ Brix, $\mathrm{pH}$ and fermentation temperature. Am. J. Enol. Vitic. 17, 20-26.

SCOTT, A.J. \& KNOTT, M., 1974. A cluster analysis method for grouping means in the analysis of variance. Biometrics. 30, 507-512.

STRYDOM, M., KIRSCHBAUM, A.F. \& TROMP, A., 1982. Ergosterol concentration of several different Saccharomyces cerevisiae yeast strains. S. Afr. J. Enol. Vitic. 3, 23-28.

TROMP, A., 1980. Die invloed van verskillende faktore op gisting en wyngehalte met spesiale verwysing na slepende gisting. Short course in Oenology and cellar planning, 18-20 November 1980, Nietvoorbij. V O R I (internal publication).

TROMP, A. \& CONRADIE, W.J., 1979. An effective system for the sensory evaluation of experimental wines. Am. J. Enol. Vitic. 30, 278-283.

VAN ROOYEN, P.C. \& TROMP, A., 1982. The effect of fermentation time (as induced by fermentation and must conditions) on the chemical profile and quality of a Chenin blanc wine. S. Afr. J. Enol. Vitic. 3, 75-80.

VOS, P.J.A., CROUS, E. \& SWART, L., 1980. Fermentation and the optional nitrogen balance of musts. Wynboer 582, 58-63.

VOS. P.J.A. \& GRAY, R.S., 1979. The origin and control of hydrogen sulphide during fermentation of grape must. Am. J. Enol. Vitic. 30, 187-197.

VOS, P.J.A., ZEEMAN, W. \& HEYMANN, H., 1978. The effect on wine quality of di-ammonium phosphate additions to musts. Proc. S. Afr. Soc. Enol. Vitic., 87-104. 